\title{
PELAKSANAAN PARTISIPASI MASYARAKAT DALAM PROSES PEMBENTUKAN PERATURAN DAERAH (STUDI DI KOTA MATARAM)
}

\author{
${ }^{1}$ Irawan Kusumahadi, ${ }^{2}$ Kaharudin, ${ }^{3}$ Muh. Risnain \\ ${ }^{1,2,3}$ Program Studi Magister Ilmu Hukum, Fakultas Hukum, \\ Universitas Mataram, NTB, Indonesia \\ Email: herru0481@gmail.com
}

\begin{abstract}
This paper is to examine the implementation of community participation in the process of forming regional regulations in Mataram City. This study uses a sociological (empirical) juridical legal research method with a statutory approach and a sociological approach. The results of the study show that the implementation of community participation in the process of forming regional regulations in Mataram City using information technology channels through an application called Partner (community participation in the formation of regional regulations) based on mobile phones, is considered to be able to overcome obstacles in the manual participation process. has not been fully implemented in accordance with the provisions of laws and regulations, especially in fulfilling the provisions for the involvement of the community in the process of forming regional regulations which refer to Article 354 Paragraph (1), (3), (4) and (5) Law Number 23 Year 2014 regarding Regional Government as amended several times, most recently by Law Number 9 of 2015 and Article 2, 3 and Article 4 of Government Regulation Number 45 of 2017 concerning Community Participation in the Implementation of Regional Government, because the application is not supported by the legality of its utilization and human resources who manage the application. So that the implementation of community participation in the process of forming regional regulations in the City of Mataram has not been maximal and the resulting regional regulations cannot be said to have a responsive legal character.
\end{abstract}

Keywords: Participation, Local Regulation, Responsiveness

\section{A. PENDAHULUAN}

Penyelenggaraan pemerintahan daerah diarahkan untuk mempercepat terwujudnya kesejahteraan masyarakat melalui peningkatan pelayanan, pemberdayaan, dan peran serta masyarakat, serta peningkatan daya saing 
Jurnal SOSIO DIALEKTIKA 6 (1) (2021)

P-ISSN: 2540.8941 e-ISSN: 2623.2944

sosiodialektika@unwahas.ac.id
Pelaksanaan Partisipasi

Masyarakat Dalam Proses

Pembentukan Peraturan Daerah

(Studi Di Kota Mataram)

daerah dengan memperhatikan prinsip demokrasi, pemerataan, keadilan, dan kekhasan suatu daerah dalam sistem Negara Kesatuan Republik Indonesia. ${ }^{1}$

Dalam rangka mencapai tujuan mempercepat terwujudnya kesejahteraan tersebut pemerintah daerah mempunyai kewenangan membuat kebijakan daerah dalam rangka memberikan pelayanan, peningkatan peran serta, prakarsa dan pemberdayaan masyarakat dalam penyelenggaraan pemerintahan daerah itu sendiri. Dengan adanya otonomi daerah semakin mendekatkan jarak antara pengambil kebijakan dengan masyarakat. Dengan demikian pemerintah daerah dapat lebih cepat dalam merespon tuntutan masyarakat daerah sesuai dengan kemampuan yang dimiliki. ${ }^{2}$

Salah satu upaya untuk mempercepat terwujudnya kesejahteraan masyarakat melalui peran serta masyarakat atau sering disebut dengan istilah Partisipasi, dimana partisipasi masyarakat dalam penyelenggaraan pemerintahan daerah memiliki fungsi penting, antara lain sebagai sarana bagi masyarakat baik orang perseorangan, kelompok masyarakat, maupun organisasi kemasyarakatan dalam mengekspresikan kebutuhan dan kepentingannya sehingga proses pembentukan kebijakan daerah lebih aspiratif terhadap kebutuhan dan kepentingan masyarakat. Partisipasi masyarakat juga merupakan hal penting dalam mewujudkan kepedulian dan dukungan masyarakat untuk keberhasilan pembangunan di daerahnya dikarenakan jika masyarakat dapat mengetahui sejak dini proses pengambilan kebijakan yang ada dan ikut serta di dalamnya, pada akhirnya akan berdampak pada ketaatan masyarakat dalam melaksanakan kebijakan tersebut.

Partisipasi masyarakat dalam proses pengambilan kebijakan paling tidak pelibatanya dalam dua tahap utama yakni pertama, agenda setting, yaitu tahap untuk memilih masalah apa yang hendak dibahas dan

1 Konsideran menimbang huruf b Undang-Undang Nomor 23 tahun 2014 tentang pemerintahan daerah sebagaimana telah diubah beberapa kali terahir deenga Undng-Undang Nomor 9 Tahun 2015

2 Praptanugraha, Partisipasi Masyarakat Dalam Pembentukan Peraturan daerah, Jurnal Hukum No. 3 vol. 15 juli 2008: 459 - 473 
diputuskan; kedua, deciding the outcome, yaitu tahap pengambilan keputusan $^{3}$. Dengan demikian peranan masyarakat sangat diperlukan dalam menentukan masalah apa yang akan dibahas dan diputuskan serta berperan dalam pengambilan keputusan yang akan tertuang dalam kebijakan.

Dalam perspektif penyelenggaraan pemerintahan yang demokratis, partisipasi pada dasarnya bukanlah suatu konsep yang baku, ia hanya $a$ mean to an end, jadi bukan tujuan akhir itu sendiri, ${ }^{4}$ tujuan sebenarnya adalah "pengaruh yang berarti" terhadap proses penyelenggaraan pemerintahan dalam arti luas mulai dari pengambilan kebijakan, pelaksanaan, sampai dengan evaluasi kebijakan terutama yang berkenaan dengan pengelolaan sumber daya publik baik berupa sumber daya alam, keuangan dan yang lainnya. Oleh karenanya, pola partisipasi sangat bervariasi, tergantung pada situasi dan kondisi di suatu tempat dan konteks yang menyertainya. Walau demikian perdebatan seputar seberapa perlu partisipasi publik harus dilakukan, bagaimana teknis yang tepat untuk melakukannya, dan seberapa jauh jaminan terhadap substansi yang berasal dari proses partisipasi harus tersedia, terus berkembang. Selain itu yang tidak kalah pentingnya juga adalah sejauh mana produk kebijakan itu responsif terhadap kebutuhan dan tuntutan masyarakat. Mahfud $\mathrm{MD}^{5}$, mengemukakan produk hukum responsif adalah produk hukum yang karakternya mencerminkan pemenuhan atas tuntutan-tuntutan individu maupun berbagai kelompok sosial dan lebih dapat memenuhi rasa keadilan di dalam masyarakat. Sedangkan produk hukum konservatif/ortodoks adalah produk hukum yang karakternya mencerminkan visi politik pemegang kekuasaan dominan sehingga pembuatannya tidak mengundang partisipasi dan aspirasi masyarakat secara sungguh-sungguh.

${ }^{3}$ Gafar, Afan. Politik Indonesia Transsisi menuju Demokrasi, Pustaka Pelajar,Yogyakarta, 2004, hlm.6.

${ }^{4}$ Santosa, Mas Achmad. Good Governance dan Hukum Lingkungan, (Jakarta: ICEL, 2001), hlm. 4849.

${ }^{5}$ Mahfud MD, Moh. Politik Hukum Di Indonesia, Jakarta, Rajawali Pers, 2011, hlm 31. 
Partisipasi masyarakat dalam pembentukan peraturan Perundangundangan merupakan suatu cerminan dari sebuah Negara Demokrasi dimana keikutsertaan rakyat merupakan suatu hal yang niscaya, meskipun rakyat sudah diresperentasikan oleh Wakil-wakil di lembaga Perwakilan Rakyat (DPR dan DPRD) tidak berarti suatu Rancangan Peraturan Daerah tersebut tidak akan berpotensi terjadi penyimpangan substansinya pada proses pembahasannya bersama Kepala Daerah, Tahapan terakhir proses legislasi adalah sebuah black box, yaitu proses pengajuan draft Peraturan Daerah untuk dibahas dalam sidang paripurna sampai pengundangannya dalam lembaran daerah. Pada tahapan ini, proses bersifat politis dan sangat menentukan nasib dari peraturan yang diajukan tersebut. Karenanya pada setiap tahapan legislasi sangat berpotensi untuk terjadinya penyimpangan substansi Peraturan Daerah. Penyimpangan substansi ini terkait dengan kepentingan stakeholder yang berbeda terhadap peraturan yang sedang disusun, baik yang pro maupun yang kontra. Namun dengan ketelitian, argument, dan pendekatan yang baik dan rasional pada saat pembahasan, biasanya penyimpangan tersebut dapat dihalangi dan dikembalikan pada substansi yang benar. ${ }^{6}$

Dalam penyelenggaraan pemerintahan daerah kebijakan dituangkan kedalam produk hukum daerah, baik produk hukum daerah berbentuk pengaturan maupun penetapan. Produk hukum daerah yang bersifat pengaturan terbagi menjadi 2 (dua) yakni Peraturan Daerah dan Peraturan Kepala Daerah. Untuk Peraturan Daerah di Kota Mataram proses pembentukannya secara umum sama dengan daerah lainnya secara nasional yakni dilakukan melalui beberapa tahapan, mulai dari tahapan perencanaan, penyusunan, pembahasan, pengesahan atau penetapan, sampai dengan tahapan pengundangan. Pelibatan masyarakat secara luas umumnya dapat dilakukan pada semua tahapan proses pembentukan peraturan daerah, namun pada pelaksanaannya pelibatan masyarakat sering ditekankan hanya

6 Darmini. "Pembentukan Peraturan Daerah Yang Responsif Melalui Inisiatif DPRD Kota Mataram". Jurnal IUS Kajian Hukum dan Keadilan Volume VI Nomor 2 Tahun 2018, hlm.3. 
pada tahapan penyusunan dan pembahasan, padahal tahapan pengesahan atau penetapan dan pengundangan dua tahapan yang sangat penting juga. Pada semua tahapan ini penulis mencoba mengkaitkan dan mejadikan dasar apakah sebuah produk hukum daerah itu dapat dikualifikasikan kedalam produk hukum responsif atau konservatif/ortodoks. Proses Pembentukan Peraturan Daerah sebagai salah satu aspek penting dari penyelenggaraan pemerintahan daerah, dimana proses ini perlu mendapat perhatian dan pengembangan dalam pelaksanaannya kearah yang lebih baik, yang pada ahirnya dapat terwujudnya tujuan dari penyelenggaraan pemerintahan daerah itu sendri.

Kota Mataram sebagai salah satu Kota diantara Kabupaten/Kota di Nusa Tenggara Barat merupakan sebuah Daerah otonom, sehingga memiliki kewenangan untuk melaksanakan otonomi, dan di dalam melaksanakan otonomi daerah berhak membentuk Peraturan Daerah sebagai perangkat regulasi untuk menjadi dasar legalitas untuk melaksanakan pemerintahan dan pembangunan guna memberikan pelayanan kepada masyarakat di daerahnya. Penulisan mengenai pembentukan Peraturan Daerah di Kota Mataram sebetulnya bukanlah sesuatu yang baru sama sekali, sepanjang penelitian dan penulisan, ditemukan 1 (satu) tesis yang terkait, yaitu tesis ditulis tahun 2018 oleh , Janur Yudistyo Prabowo dalam Tesisnya yang berjudul "Pembentukan Peraturan Daerah Yang Aspiratif Melalui Inisiatif DPRD Kota Mataram", penelitian ini lebih menitik beratkan pada Pembentukan Peraturan Daerah yang bersumber dari Inisiatif DPRD Kota Mataram, dimana diketahui bahwa Pertama, pembentukan peraturan daerah dalam tahapan penyusunan dan pembahasannya tidak semua didahului dengan naskah akademik dimana dari 8 Peraturan Daerah Kota Mataram yang direncanakan hanya 1 (satu) yang memiliki Naskah Akademik dan selebihnya tidak memiliki. Kedua, pelaksanaan konsultasi publik dalam rangka menyerap aspirasi masyarakat dalam pembentukan peraturan daerah, dinyatakan bahwa tidak semua Rancangan Peraturan Daerah melalui proses konsultasi publik, mengingat terbatasnya anggaran, sehingga dalam 
pelaksanaannya diprioritaskan untuk rancangan peraturan daerah yang dinilai menyentuh langsung terhadap kepentingan masyarakat Kota Mataram, masyarakat yang dilibatkan pun tidak secara menyeluruh, keterlibatan masyarakat/stakeholders sangatlah terbatas dalam memberikan masukan dalam penyempurnaan sebuah rancangan peraturan daerah padahal masyarakat/stakeholders sangat dibutuhkan dalam memberikan masukan, apalagi yang menyangkut pembebanan kepada masyarakat.

Dalam Proses pembentukan Peraturan Daerah Pemerintahan Kota Mataram pada tataran pelaksanaannya dapat dikatakan sudah memberikan ruang partisipasi masyarakat di dalam pembentukannya, akan tetapi memiliki perbedaan yang sangat mendasar antara Peraturan Daerah yang berasal dari inisiatif DPRD Kota Mataram dengan Daerah yang berasal dari inisiatif Pemerintah Kota Mataram, dimana Peraturan Daerah yang berasal dari inisiatif DPRD Kota Mataram cenderung berkarakter responsif karena bersifat aspiratif yang cenderung merespon akan kebutuhan masyarakat (bottom up) dan proses pembuatannya pun bersifat partisipatif, serta dari segi penafsiran maka produk hukumnya memberikan sedikit peluang bagi pemerintah untuk membuat penafsiran sendiri melalui berbagai peraturan pelaksanaan. Sedangkan Peraturan Daerah yang diajukan oleh Kepala Daerah cenderung berkarakter ortodoks karena bersifat positivisinstrumentalis, artinya memuat materi yang lebih merefleksikan visi sosial dan politik pemegang kekuasaan atau memuat materi yang lebih merupakan alat untuk mewujudkan kehendak dan kepentingan program pemerintah (top down). Kemudian proses pembuatannya yang bersifat sentralistik, serta dari segi penafsiran maka produk hukumnya memberi peluang luas kepada pemerintah untuk membuat berbagai interpretasi dengan berbagai peraturan lanjutan.

Berbeda halnya dengan kajian yang diteliti oleh penulis, dimana fokus kajiannya mengenai pelaksanaan partisipasi dalam pembentukan Peraturan Daerah oleh Pemerintah Daerah melalui aplikasi bebasis handphone yang diberi nama Partner (patisipasi masyarakat dalam pembentukan regulasi 
daerah) di Kota Mataram, pelaksanaan partisipasi tersebut sebagai amanat Undang-Undang Nomor 23 Tahun 2014 tentang Pemerintahan Daerah dan Undang-Undang Nomor 12 Tahun 2011 tentang Pembentukan Peraturan Perundang-undangan serta Peraturan Pemerintah Nomor 45 Tahun 2017 Tentang Partisipasi Masyarakat Dalam Penyelenggaraan Pemerintahan Daerah. Kemudian dikaitkan dalam pelaksanaannya di Pemerintah Kota Mataram produk hukum berupa Peraturan Daerah yang diajukan oleh Kepala Daerah sebagamana yang disebutkan di atas dari penelitian sebelumnya cenderung berkarakter ortodoks yang proses pembuatannya yang bersifat sentralistik (top down).

\section{B. METODE PENELITIAN}

Penelitian ini adalah penelitian hukum normatif dan empiris yaitu mengkaji bahan hukum primer dari Peraturan Perundang-undangan dan bahan hukum skunder berupa pendapat para pakar. Selain itu juga akan dikaji implementasi Peraturan Perundang-undangan yakni Undang-Undang Nomor 12 Tahun 2011 tentang Pembentukan Peraturan Perundangundangan dengan menggunakan wawancara sebagai penunjang penelitian normatif.

Metode pendekatan yang digunakan dalam penelitian yuridis sosiologis empiris ini adalah Pendekatan konseptual (Conceptual Approach), Pendekatan Perundang-undangan (Statute Approach), dan Pendekatan Sosiologis (Sociological Approach). Sumber data yang dibutuhkan dalam penelitian ini adalah data primer yang diperoleh langsung dari hasil wawancara yang dilakukan baik terhadap responden maupun informan. Teknik dan alat pengumpulan data primer data didapat melalui Wawancara (interview). Metode interview ini dilakukan melalui wawancara (interview) terstruktur dan mendalam (depth interview) terhadap responden dan informan. Sumber data sekunder, yakni sumber data/bahan hukum yang menjelaskan sumber data primer, karena itu bahan hukum ini diperoleh dari 
buku-buku, makalah, jurnal yang ditulis oleh para ahli serta dari dokumen/risalah.

Pengumpulan bahan hukum dilakukan dengan menginventarisir, menyusun berdasarkan subyek, selanjutnya dikaji/dipelajari kemudian diklasifikasi sesuai dengan pokok masalah yang dibahas dalam penelitian ini. Teknik pengumpulan ini disebut dengan teknik studi dokumentasi dengan menggunakan alat bantu kartu kutipan berdasarkan pengarang/penulis maupun tema atau masalah pokok (obyek). Setelah data dan informasi terkumpul, selanjutnya dianalisis secara deskriptif analitik untuk mendapat jawaban dari permasalahan penelitian. Data-data dan informasi dianalisis dengan pemaparan secara sistematis sehingga diperoleh gambaran dan kesimpulan dari permasalahan yang dibahas.

\section{HASIL DAN PEMBAHASAN}

Mekanisme pelaksanaan partisipasi masyarakat dalam proses pembentukan Peraturan Daerah di Kota Mataram.

Pengaturan hak partisipasi publik ini telah ditegaskan oleh berbagai Peraturan Perundang-undangan selain yang ada dalam Undang-Undang Nomor 12 Tahun 2011, misalnya Undang-Undang Nomor 36 Tahun 2009 Tentang Pengelolaan Lingkungan Hidup, Undang-Undang Nomor 26 Tahun 2007 Tentang Penataan Ruang, Undang-Undang Nomor 23 Tahun 2014 tentang Pemerintahan Daerah, sebagaimana telah diubah beberapa kali terakhir dengan Undang-Undang Nomor 9 Tahun 2015, yang merupakan dasar pijakan bagi pelaksanaan otonomi daerah yang memberikan ruang partisipasi publik seperti tercantum dalam pasal 237 ayat (3) berbunyi: "Masyarakat berhak memberikan masukan secara lisan dan/atau tertulis dalam pembentukan Perda", dan Peraturan Pemerintah Nomor 45 Tahun 2017 tetang Partisipasi Masyarakat Dalam Penyelenggaraan Pemerintahan Daerah. Salah satu cakupan partisipasi masyarakat menurut Undang-Undang Nomor 23 Tahun 2014 tentang Pemerintahan Daerah sebagaimana telah diubah beberapa kali terakhir dengan UndangUndang Nomor 9 Tahun 2015 
adalah dalam hal penyusunan peraturan daerah.10 Partisipasi masyarakat dilakukan dalam bentuk:

(a) Konsultasi publik;

(b) Musyawarah;

(c) Kemitraan;

(d) Penyampaian aspirasi;

(e) Pengawasan; dan/atau

(f) Keterlibatan lain sesuai dengan ketentuan peraturan perundangundangan.

Sementara itu ketentuan poin $\mathrm{f}$ tersebut jika dikaitkan dengan pengaturan partisipasi masyarakat dalam Undang-Undang Nomor 12 Tahun 2011 tentang Pembentukan Peraturan Perundang-undangan, maka akan diketahui jika masyarakat berhak memberikan masukan secara lisan dan/atau tertulis dalam pembentukan peraturan daerah, dimana masukan secara lisan dan/atau tertulis tersebut dapat dilakukan melalui: rapat dengar pendapat umum, kunjungan kerja, sosialisasi dan/atau seminar, lokakarya, dan/atau diskusi.

Partisipasi Publik merupakan suatu proses masyarakat turut serta mengambil bagian dalam pembuatan keputusan dan dalam kegiatankegiatan nyata pemerintah, pelaksanaannya bisa dalam bentuk diskusi, publik hearing, workshop, survey atau interview terhadap masing-masing individu anggota masyarakat. Dalam hal ini pembentukan Peraturan Daerah penyerapan aspirasi publik dapat dimulai dengan mengeksplorasi permasalahan yang dihadapi masyarakat. Daftar masalah dan inisiatif warga merupakan bagian terpenting bagi penyusunan draft naskah akademik kemudian disosialisasikan melalui konsultasi publik. Adapun peserta konsultasi publik ini adalah warga yang relevan dengan isu/usulan warga tersebut seperti aktifis, Lembaga Swadaya Masyarakat (LSM), Organisasi Masyarakat, Pers, Mahasiswa dan Akedemisi, Anggota DPRD, Tokoh Masyarakat dan, Pejabat Pemerintah Kota/Kabupaten. 
Sehubungan dengan partisipasi aktif masyarakat dalam pembentukan Peraturan Daerah, maka perlu juga dikemukakan pandangan W. Riawan Tjandra dan Kresno Budi Sudarsono, yang menegaskan terdapat tiga akses (three accesses) yang perlu disediakan bagi masyarakat dalam penyelenggaraan pemerintahan ${ }^{7}$, yaitu:

(1) Akses terhadap informasi yang meliputi 2 (dua) tipe yaitu:
(a) Hak akses informasi pasif
(b) Hak informasi aktif.

(2) Akses partisipasi dalam pengambilan keputusan (public participation in decision making) meliputi:
(a) Hak masyarakat untuk mempengaruhi pengambilan keputusan.
(b) Partisipasi dalam penetapan kebijakan, rencana dan program pembangunan.
(c) Partisipasi dalam pembentukan peraturan perundang- undangan.

(3) Akses terhadap keadilan (access to justice) Menyediakan mekanisme bagi masyarakat untuk menegakkan hukum. Sifat dasar dan peran serta adalah:
(a) Keterbukaan (openness)
(b) Transparansi (transparency).

Akses yang pertama tentu ini berkaitan erat dengan Undang-Undang Nomor 14 Tahun 2008 Tentang Keterbukaan Informasi Publik, terutama pada pasal 7, 8 dan 9, dimana Badan Publik wajib menyediakan, memberikan dan/atau menerbitkan Informasi Publik yang berada di bawah kewenangannya kepada Pemohon Informasi Publik, selain informasi yang dikecualikan sesuai dengan ketentuan dan Badan Publik wajib menyediakan Informasi Publik yang akurat, benar, dan tidak menyesatkan.) Kewajibankewajiban yang harus dilakukan oleh Badan Publik salah satunya dalam proses penyusunan peraturan daerah, dimana pemerintah dengan DPRD harus menyampaikan kepada publik proses penyusunan peraturan daerah

7 W. Riawan Tjandra dan Kresno Budi Sudarsono, Legislative Drafting: Teori dan Teknik Pembuatan Peraturan Daerah, Penerbit Universitas Atmajaya, Yogyakarta, 2009, HIm. 85. 
tersebut, sehingga tidak terjadi penyimpangan terhadap penyusunan peraturan daerah.

Akses kedua, dimana masyarakat diberikan pelibatan secara langsung dalam kebijakan pemerintah, dalam berbagai penyusunan peraturan daerah sudah dilakukan oleh pemerintah daerah,sehingga masyarakat ikut serta secara aktif dalam pengambilan keputusan yang dilakukan oleh pemerintah daerah terutama dalam penyusunan peraturan daerah, dan

Akses ketiga adalah keadilan terhadap penegakan hukum dari aturan yang dibuat, lebih melihat kepada kepentingan masyarakat. Berdasarkan pasal 237 ayat (3) dan ayat (4) Undang-Undang Nomor 23 Tahun 2014 tentang Pemerintahan Daerah sebagaimana telah diubah beberapa kali terakhir dengan Undang-Undang Nomor 9 Tahun 2015, Masyarakat berhak memberikan masukan secara lisan dan/atau tertulis dalam pembentukan Perda dan pembentukan Perda dilakukan secara efektif dan efisien.

Oleh karena itu, ada hal yang menjadi penting, yaitu setiap rancangan peraturan daerah harus diumumkan melalui media masa lokal atau media lainya yang dapat dipakai sebagai upaya untuk menampung aspirasi masyarkat terhadap peraturan daerah tersebut. Untuk memudahkan masyarakat dalam memberikan masukan secara lisan dan/atau tertulis setiap Rancangan Peraturan Perundang undangan harus dapat diakses dengan mudah oleh masyarakat, sebagaiamana disebutkan dalam ketentuan Pasal 96 ayat (4) Undang-Undang Nomor 12 Tahun 2011 tentangPembentukan Peraturan Perundang-undangan.

Perlu diketahui bahwa Peraturan Daerah Kabupaten/ Kota termasuk dalam jenis dan hierarki Peraturan Perundang-undangan sebagaimana tercantum dalam Pasal 7 ayat (1) Undang-Undang Nomor 12 Tahun 2011 tentang Pembentukan Peraturan Perundang-undangan, sehingga dalam pembentukannya harus sesuai dengan peraturan perundang-undangan yang berlaku. Dimana berdasarkan ketentuan Pasal 1 angka 1 Undang-Undang Nomor 12 Tahun 2011 tentang Pembentukan Peraturan Perundangundangan, menyebutkan bahwa Pembentukan Peraturan Perundang- 
Jurnal SOSIO DIALEKTIKA 6 (1) (2021)

P-ISSN: 2540.8941 e-ISSN: 2623.2944

sosiodialektika@unwahas.ac.id
Pelaksanaan Partisipasi

Masyarakat Dalam Proses

Pembentukan Peraturan Daerah

(Studi Di Kota Mataram)

undangan adalah pembuatan Peraturan Perundang-undangan yang mencakup tahapan perencanaan, penyusunan, pembahasan, pengesahan atau penetapan, dan pengundangan.

Pembentukan Peraturan Daerah di Pemerintahan Kota Mataram dilakukan melalui beberapa tahapan sebagai berikut:

(1) Tahapan Perencanaan :

Dalam tahapan ini dilakukan perencanaan terkait Peraturan Daerah yang nantinya akan ditetapkan sebagai Program Pembentukan Peraturan Daerah (Propemperda). Penyusunan Program Pembentukan Peraturan Daerah (Propemperda) tersebut berdasarkan atas:

(a) perintah peraturan perundang-undangan lebih tinggi;

(b) rencana pembangunan daerah;

(c) penyelenggaraan otonomi daerah dan tugas pembantuan; dan

(d) aspirasi masyarakat daerah.

Sebagaimana hal tersebut diatas dimuat dalam ketentuan pasal 15 ayat (4) Peraturan Menteri Dalam Negeri Nomor 80 Tahun 2015 tentang Pembentukan Produk Hukum Daerah sebagaimana telah diubah dengan Peraturan Menteri Dalam Negeri Nomor 120 Tahun 2018.

Agar memberikan gambaran yang jelas terkait perencanaan Peraturan Daerah, maka akan dipaparkan oleh penulis secara runtut :

(a) Walikota Mataram memerintahkan pimpinan Satuan Kerja Perangkat Daerah (SKPD) menyusun Program Pembentukan Peraturan Daerah (Propemperda) di lingkungan pemerintah daerah.

(b) Propemperda ditetapkan untuk jangka waktu 1 (satu) tahun berdasarkan skala prioritas pembentukan Rancangan Perda.

(c) Penyusunan dan penetapan Propemperda dilakukan setiap tahun sebelum penetapan Rancangan Perda tentang APBD provinsi dan APBD kabupaten/kota. 
(d) Penyusunannya dikoordinasikan dengan Bagian Hukum Setda Kota Mataram, dimana dapat juga mengikutsertakan instansi vertikal yang terkait sesuai dengan kewenangan, materi muatan, atau kebutuhan dalam pengaturan.

(e) Setelah penyusunan selesai, maka hasil penyusunan Propemperda tersebut diajukan oleh Bagian Hukum Setda Kota Mataram kepada Walikota Mataram melalui Sekretaris Daerah.

(f) Kemudian Walikota Mataram menyampaikan hasil penyusunan Propemperda di lingkungan pemerintah daerah kepada Badan Pembentukan Peraturan Daerah (Bapemperda) melalui pimpinan DPRD.

Dalam tahapan ini perencanaan Peraturan Daerah yang disusun disepakati oleh Kepala Daerah dengan Dewan Perwakilan Rakyat Daerah (DPRD) Kota Mataram menjadi Program Pembentukan Peraturan Daerah (Propemperda) dan ditetapkan dengan Keputusan DPRD Kota Mataram dalam Rapat Paripurna DPRD. Dalam tahapan ini perencanaan Peraturan Daerah tidak terpublikasikan lewat aplikasi Partner yang dimiliki Pemerintah Kota Mataram, hanya saja pada sidang Rapat Paripurna DPRD Kota Mataram tersebut dinyatakan terbuka untuk umum, sehingga bisa diakses oleh siapapun dalam bentuk permintaan manual.

(2) Tahapan Penyusunan :

Dalam tahapan penyusunan ini rancangan Peraturan Daerah memiliki mekanisme sebagai berikut :

(a) Walikota Mataram memerintahkan kepada pimpinan SKPD menyusun Rancangan Perda berdasarkan Propemperda. selanjutnya Pimpinan SKPD menyusun Rancangan Perda dengan disertai naskah akademik dan/atau penjelasan atau keterangan yang memuat pokok pikiran dan materi muatan yang diatur. Kemudian setelah rancangan tersebut disusun oleh Satuan Kerja Perangkat Daerah (SKPD) terkait maka 
Jurnal SOSIO DIALEKTIKA 6 (1) (2021)

P-ISSN: 2540.8941 e-ISSN: 2623.2944

sosiodialektika@unwahas.ac.id
Pelaksanaan Partisipasi

Masyarakat Dalam Proses

Pembentukan Peraturan Daerah

(Studi Di Kota Mataram)

selanjutnya diajukan kepada Bagian Hukum Setda Kota Mataram untuk untuk pengharmonisasian, pembulatan, dan pemantapan konsepsi terhadap Rancangan Peraturan Daerah yang telah disusun. Kemudian Bagian Hukum Setda Kota Mataram menjadwalkan kegiatan konsultasi publik terhadap Rancangan Peraturan Daerah tersebut, hal ini dimaksudkan kepada masyarakat, akademisi, organisasi yang terkait untuk menyampaikan aspirasi dan memberikan kritikan, masukan baik secara lisan maupun tertulis. ${ }^{8}$

(b) Setelah proses penyusunan telah selesai dilaksanakan, maka Walikota Mataram menyampaikan Rancangan Perda tersebut kepada pimpinan DPRD untuk dilakukan pembahasan.

Berdasarkan hasil wawancara dengan Janur Sulistyo Prabowo, SH., MH, Kasubag Peraturan Perundangan-undangan Bagian Hukum Setda Kota Mataram, diketahui bahwa Rancangan Peraturan Daerah yang berasal dari Kepala Daerah dalam hal ini yang diajukan oleh Organisai Perangkat Daerah (OPD) terkait "tidak semua didahului dengan naskah akademik", adapun ketentuan yang mengamanatkan mengenai disertainya naskah akademik dalam penyusunan Rancangan Peraturan Daerah dimuat dalam Pasal 56 ayat (2) dan Pasal 63 Undang-Undang Nomor 12 Tahun 2011 tentang Pembentukan Peraturan Perundang-undangan, berlaku secara mutatis mutandis terhadap penyusunan Peraturan Daerah Kabupaten/Kota, yang pada pokoknya menyatakan bahwa : Rancangan Peraturan Daerah Provinsi disertai dengan penjelasan atau keterangan dan/atau Naskah Akademik. Demikian juga dalam Pasal 22 sampai dengan Pasal 24 Peraturan Menteri Dalam Nomor 80 Tahun 2015 tentang Pembentukan Produk Hukum Daerah, sebagaimana telah diubah dengan Peraturan Menteri Dalam Negeri Nomor 120 Tahun 2018,

\footnotetext{
${ }^{8}$ Wawancara dengan, Janur Yudistyo Prabowo, $\mathrm{SH}, \mathrm{MH}$, Kasubag Peraturan Peraturan Perundangundangan Bagian Hukum Setda Kota Mataram, pada tanggal 9 Agustus 2020.
} 
Jurnal SOSIO DIALEKTIKA 6 (1) (2021)

P-ISSN: 2540.8941 e-ISSN: 2623.2944

sosiodialektika@unwahas.ac.id
Pelaksanaan Partisipasi

Masyarakat Dalam Proses

Pembentukan Peraturan Daerah

(Studi Di Kota Mataram)

mengamanatkan mengenai disertainya naskah akademik dalam penyusunan Rancangan Peraturan Daerah, berlaku secara mutatis mutandis terhadap penyusunan Peraturan Daerah Kabupaten/Kota.

Selain itu, bahwa Urgensi dari naskah akademis dalam proses pembentukan Peraturan Daerah antara lain naskah akademis merupakan media nyata bagi partisipasi masyarakat dalam proses pembentukan peraturan daerah. Naskah akademis memaparkan alasanalasan, fakta-fakta dan latar belakang tentang hal-hal yang mendorong disusunnya suatu masalah atau persoalan, sehingga sangat penting dan mendesak diatur dalam peraturan daerah. Naskah akademis menjelaskan aspek filosofis, aspek sosiologis, yuridis dan aspek politik yang berkaitan dengan peraturan daerah yang akan dibuat. Naskah akademis memberikan gambaran mengenai substansi, materi dan ruang lingkup dari Perda yang akan dibuat, dan Naskah Akedemis (NA) digunakan sebagai penyaring, penyembatani dan upaya untuk meminimalisir unsur-unsur kepentingan politik dari pihak pembentuk Peraturan Daerah (Perda). Di samping itu, NA memberikan pertimbangan bagi lembaga eksekutif dan legislatif dalam mengambil keputusan mengenai peraturan yang akan dibuat. Berangkat dari pemahaman terhadap urgensi naskah akademis dalam pembuatan peraturan daerah, keberadaan NA memang sangat diperlukan untuk sebuah Perda yang baik, aspiratif, partisipatif dan tidak menimbulkan masalah di kemudian hari. Kualitas NA pun perlu mendapatkan perhatian serius, NA yang tidak berkualitas akan menghasilkan peraturan daerah yang tidak berkualitas pula, untuk itulah diperlukan strategi dan proses penyusunan NA, sehingga menghasilkan NA partisipatif yang berkualitas. Keberadaan NA akan mengidentifikasi permasalahan dan kebutuhan masyarakat terhadap adanya peraturan daerah. Jadi berdasarkan penyampaian dari Janur Sulistyo Prabowo, SH., MH, Kasubag Peraturan Perundangan-undangan Bagian Hukum Setda Kota Mataram di atas tidak semua didahului dengan naskah 
akademik dan penyusunan Rancangan Peraturan Daerah yang disertai dengan naskah akademik.

Begitu juga halnya pelaksanaan konsultasi publik dalam rangka menyerap aspirasi masyarakat dalam pembentukan peraturan perundang-undangan, dimana diketahui berdasarkan hasil wawancara yang sama ${ }^{9}$, menyebutkan bahwa tidak semua Rancangan Peraturan Daerah melalui proses konsultasi publik, mengingat terbatasnya anggaran dalam 1 (satu) Tahun Anggaran, Sehingga dalam pelaksanaannya diprioritaskan untuk Rancangan Peraturan Daerah yang dinilai menyentuh langsung terhadap kepentingan masyarakat Kota Mataram. Masyarakat yang dilibatkan pun tidak secara menyeluruh akan tetapi hanya masyarakat yang terkait atau terkena dampak langsung maupun tidak langsung dari penetapan Peraturan Daerah (stakeholder/ pemangku kepentingan di luar DPRD Kota Mataram dan Pemerintah Daerah Kota Mataram).

Dari keterangan yang disampaikan oleh Bagian Hukum Setda Kota Mataram tersebut, sudah dipastikan bahwa keterlibatan masyarakat/stakeholders dalam tahapan penyusunan ini sangatlah terbatas dalam memberikan masukan dalam penyempurnaan sebuah Rancangan Peraturan daerah. Padahal masyarakat/stakeholders sangat dibutuhkan dalam memberikan masukan, apalagi yang menyangkut pembebanan kepada masyarakat.

(3) Tahapan Pembahasan :

Di dalam Pembahasan Peraturan Daerah untuk mendapatkan persetujuan bersama pembahasan Rancangan Peraturan Daerah tersebut dilakukan melalui 2 (dua) tingkat pembicaraan yaitu pembicaraan tingkat I dan pembicaraan tingkat II, dengan mekanisme sebagai berikut :

(a) Pembicaraan tingkat I

\footnotetext{
${ }^{9}$ Wawancara dengan, Janur Yudistyo Prabowo, $\mathrm{SH}, \mathrm{MH}$, Kasubag Peraturan Peraturan Perundangundangan Bagian Hukum Setda Kota Mataram, pada tanggal 9 Agustus 2020.
} 
Pada pembicaraan tingkat I ini dilakukan sebagai berikut :

(1) Penjelasan kepala daerah dalam rapat paripurna mengenai Rancangan Perda;

(2) Pemandangan umum fraksi terhadap Rancangan Perda; dan

(3) Tanggapan dan/atau jawaban kepala daerah terhadap pemandangan umum fraksi.

(b) Pembicaraan tingkat II

Pembicaraan pada tingkat ini, meliputi :

(1) pengambilan keputusan dalam rapat paripurna yang didahului dengan:

(2) Penyampaian laporan hasil kerja pimpinan komisi/pimpinan gabungan komisi/pimpinan panitia khusus yang berisi pendapat fraksi dan hasil pembahasan.

(3) Permintaan persetujuan dari anggota secara lisan oleh pimpinan rapat paripurna.

(4) Pendapat Akhir Walikota Mataram.

Dalam hal persetujuan tersebut tidak dapat dicapai secara musyawarah untuk mufakat, keputusan diambil berdasarkan suara terbanyak. Dalam hal rancangan Perda tidak mendapat persetujuan bersama antara DPRD dan Kepala Daerah, Rancangan Perda tersebut tidak boleh diajukan lagi dalam persidangan DPRD masa itu. Rancangan Perda dapat ditarik kembali sebelum dibahas bersama oleh DPRD dan Kepala Daerah.

Penarikan kembali Rancangan Perda tersebut oleh kepala daerah, disampaikan dengan surat kepala daerah disertai alasan penarikan. Sedangkan penarikan kembali Rancangan Peraturan Daerah tersebut oleh DPRD, dilakukan dengan keputusan pimpinan DPRD dengan disertai alasan penarikan. Dimana Rancangan Perda yang ditarik kembali tidak dapat diajukan lagi pada masa sidang yang sama. 
Rancangan Perda yang sedang dibahas hanya dapat ditarik kembali berdasarkan persetujuan bersama DPRD dan kepala daerah dan hanya dapat dilakukan dalam rapat paripurna DPRD yang dihadiri oleh Kepala Daerah.

Dapat dipastikan bahwa keterlibatan masyarakat/stakeholders dalam tahapan penyusunan ini sangatlah terbatas dalam memberikan masukan dalam penyempurnaan sebuah Rancangan Peraturan daerah.

Dalam tahapan pembahasan ini rancangan Peraturan Daerah belum dapat melibatkan banyak pihak melalui aplikasi Partner dikarenakan belum adanya operator yang ditunjuk sebagai pelaksana pengoperasian aplikasi Partner tersebut, dengan demikian pelibatan masyarakat dalam tahapan ini sangat terbatas yakni hanya pada peserta undangan sidang Rapat Paripurna DPRD Kota Mataram saja, itupun dikarenakan sidang Rapat Paripurna DPRD Kota Mataram tersebut dinyatakan terbuka untuk umum.

(5) Tahapan Pengesahan atau Penetapan :

Rancangan Perda yang telah disetujui bersama oleh DPRD Kota Mataram dan Walikota Mataram serta telah difasilitasi dan/atau dievaluasi oleh Gubernur, disampaikan oleh pimpinan DPRD Kota Mataram kepada Walikota Mataram untuk ditetapkan menjadi Peraturan Daerah. Penyampaian Rancangan Peraturan Daerah tersebut dilakukan dalam jangka waktu paling lambat 7 (tujuh) hari terhitung sejak tanggal persetujuan bersama. Walikota Mataram menetapkan Rancangan Peraturan Daerah dengan membubuhkan tanda tangan paling lambat 30 (tiga puluh) hari sejak Rancangan Peraturan Daerah disetujui bersama oleh DPRD Kota Mataram dan Walikota Mataram. Dalam hal kepala daerah tidak menandatangani Rancangan Perda, maka Rancangan Perda tersebut sah menjadi Peraturan Daerah dan wajib diundangkan dalam lembaran daerah. 
Pada tahapan ini dapat disebut sebagai tahapan sangat penting, karena sebagai bagian dari tahapan ahir dari rangkain tahapan pembentukan Peraturan Daerah sebelum pengundangan sebagai penghujungnya, keberadaan substansi yang diatur didalamnya akan sesuai atau tidak dengan hasil penyempurnaan yang telah disetujui bersama oleh Walikota Mataram dan DPRD Kota Mataram yang juga sebelumnya telah melalui tahapan pembahasan dan persetujuan penyempurnaan banyak pihak atas substansi yang akan diatur dalam sebuah Peraturan Daerah tersebut.

(6) Tahapan Pengundangan :

Peraturan Daerah yang telah ditetapkan, selanjutnya diundangkan dengan menempatkannya di dalam lembaran daerah oleh Sekretaris Daerah Kota Mataram, sedangkan penjelasan Peraturan Daerah dicatat di dalam tambahan lembaran daerah. Pengundangan Peraturan daerah tersebut sebagai syarat hukum agar setiap orang mengetahuinya (Pasal 86 ayat (1) Undang-Undang Nomor 12 Tahun 2011 tentang Pembentukan Peraturan Perundang-undangan). Kemudian ketentuan lebih lanjut di atur dalam Pasal 107 dan Pasal 121 Peraturan Menteri Dalam Negeri Nomor 80 Tahun 2015 tentang Pembentukan Produk Hukum Daerah sebagaimana telah diubah dengan Peraturan Menteri Dalam Negeri Nomor 120 Tahun 2018.

Pada tahapan ini juga menjadi tidak kalah penting dari tahapan sebelum-sebelumnya mengingat keabsahan keberlakuan substansi dari sebuah Peraturan Daerah yang akan diberlakukan dan dijalankan sangat ditentukan pada tahapan pengundangan ini, naskah Peraturan Daerah tersebut harus benar-benar dipastikan sama dengan naskah Peraturan Daerah hasil persetujuan bersama kepala daearah DPRD Kota Mataram dan Walikota Mataram. Walau menjadi tahapan terahir dari proses pembentukan peraturan tahapan pengundangan tidak 
Jurnal SOSIO DIALEKTIKA 6 (1) (2021)

P-ISSN: 2540.8941 e-ISSN: 2623.2944

sosiodialektika@unwahas.ac.id
Pelaksanaan Partisipasi

Masyarakat Dalam Proses

Pembentukan Peraturan Daerah (Studi Di Kota Mataram)

berarti suatu Rancangan Peraturan tersebut tidak akan berpotensi terjadi penyimpangan substansinya karena pada tahapan ini masyarakat sudah tidak dilibatkan lagi untuk memastikan yang diundangkan sama dengan hasil pembahsan dan penyempurnaan. Pandangan ini sejalan dengan yang disampaikan Darmini ${ }^{10}$ bahwa Tahapan terakhir proses legislasi adalah sebuah black box, yaitu proses pengajuan draft Peraturan Daerah untuk dibahas dalam sidang paripurna sampai pengundangannya dalam lembaran daerah. Pada tahapan ini, proses bersifat politis dan sangat menentukan nasib dari peraturan yang diajukan tersebut. Karenanya pada setiap tahapan pembentukan peraturan sangat berpotensi untuk terjadinya penyimpangan substansi Peraturan Daerah. Penyimpangan substansi ini terkait dengan kepentingan stakeholder yang berbeda terhadap peraturan yang sedang disusun, baik yang pro maupun yang kontra.

Apabila proses pembentukan peraturan daerah baik melalui inisiatif kepala daerah maupun melalui inisiatif DPRD Kota Matatam, maka indikator yang digunakan untuk menentukan produk hukum yang dihasilkan berkarakter responsif atau ortodoks yaitu dari segi fungsinya hukum, proses pembuatannya dan penafsiran atas sebuah produk hukum, maka Rancangan yang berasal dari inisiatif kepala daerah bersifat positivis-instrumentalis, artinya memuat materi yang lebih merefleksikan visi sosial dan politik pemegang kekuasaan atau memuat materi yang lebih merupakan alat untuk mewujudkan kehendak dan kepentingan program pemerintah (top down). Dari segi proses pembuatannya yang bersifat sentralistik dalam arti lebih didominasi oleh Pemerintah Daerah dalam hal ini SKPD terkait, kemudian dari segi penafsiran atas sebuah produk hukumnya memberi

10 Darmini. "Pembentukan Peraturan Daerah Yang Responsif Melalui Inisiatif DPRD Kota Mataram". Jurnal IUS Kajian Hukum dan Keadilan Volume VI Nomor 2 Tahun 2018, hlm.3. 
Jurnal SOSIO DIALEKTIKA 6 (1) (2021)

P-ISSN: 2540.8941 e-ISSN: 2623.2944

sosiodialektika@unwahas.ac.id
Pelaksanaan Partisipasi

Masyarakat Dalam Proses

Pembentukan Peraturan Daerah

(Studi Di Kota Mataram)

peluang luas kepada pemerintah untuk membuat berbagai interpretasi dengan berbagai peraturan lanjutan yang berdasarkan visi sepihak dari pemerintah dan tidak sekedar masalah teknis, hal tersebut dapat jelas terlihat pada ketentuan pasal 7 Peraturan Daerah Kota Mataram Nomor : 8 tahun 2008 Tentang Rencana Pembangunan Jangka Panjang Daerah (RPJPD) Kota Mataram Tahun 2005-2025, yang pada pokoknya menyatakan sebagai berikut :

"Hal-hal yang mengatur tentang pelaksanaan dan hal lain yang belum diatur dalam Peraturan Daerah ini ditetapkan dengan Keputusan Walikota sesuai dengan Peraturan Perundang-Undangan yang berlaku."

Begitu juga halnya dengan Peraturan Daerah Kota Mataram yang terbaru yakni Perubahan Atas Peraturan Daerah tentang Rencana Tata Ruang Wilayah Kota Mataram Tahun 2011 - 2031, yakni Peraturan Daerah Nomor 5 Tahun 2019 tentang Perubahan Atas Peraturan Daerah Nomor 12 Tahun 2011 Tentang Rencana Tata Ruang Wilayah Kota Mataram Tahun 2011 - 2031, , yang memberikan amanat di dalam Pasal-Pasalnya untuk diatur lebih lanjut dalam Peraturan Walikota sebanyak 21 (dua puluh satu) ketentuan.

Ketentuan sebagaimana telah dikemukakan tersebut memberikan peluang yang besar kepada pemerintah daerah untuk melakukan interpretasi sesuai dengan kepentingan sepihak pemerintah daerah, sehingga Peraturan Daerah yang berasal dari kepala daerah cenderung berkarakter ortodoks.

\section{Hambatan-hambatan dalam proses pembentukan Peraturan Daerah di}

\section{Kota Mataram}

Berdasarkan Undang-Undang Nomor 23 Tahun 2014 tentang Pemerintahan Daerah, sebagaimana telah diubah beberapa kali terakhir dengan Undang-Undang Nomor 9 Tahun 2015, maka Pemerintahan Daerah diberikan kewenangan melalui prinsip otonomi seluas-luasnya, nyata dan 
bertanggung jawab, meskipun tidak semua urusan harus diserahkan ke daerah. Urusan-urusan yang tidak diserahkan kepada daerah adalah Politik Luar Negeri, Agama, Pertahanan, Keamanan, Yustisi, Moneter, dan Fiskal Nasional. Dengan prinsip otonomi yang seluas-luasnya tersebut, daerah berwenang mengatur dan mengurus rumah tangganya sendiri dalam wadah Negara Kesatuan Republik Indonesia. Dari kewenangan tersebut, khususnya dalam pembentukan Peraturan Daerah, masing-masing daerah menggunakan kesempatan ini untuk membentuk Peraturan Daerah yang disesuaikan dengan karakteristik masyarakat, potensi dan kebutuhan terutama dalam Pemerintahan Daerah melaksanakan tugas pemerintahan dan pembangunan.

Berdasarkan ketentuan di dalam Pasal 2 Peraturan Menteri Dalam Negeri Nomor 80 Tahun 2015 tentang Pembentukan Produk Hukum Daerah sebagaimana telah diubah dengan Peraturan Menteri Dalam Negeri Nomor 120 Tahun 2018, maka dari segi sifatnya, di daerah dikenal 2 (dua) jenis yakni produk hukum daerah yang bersifat pengaturan dan produk hukum daerah yang bersifat penetapan. Kemudian dari segi bentuknya di daerah dikenal 3 (tiga) macam yakni : Peraturan Daerah (Perda), Peraturan Kepala Daerah (Perkada), dan Peraturan DPRD. Pembentukan Peraturan Daerah merupakan kewenangan Kepala Daerah bersama-sama dengan DPRD, dimana inisiatif pembentukan Peraturan Daerah dapat berasal dari kepala Daerah maupun inisiatif dari Dewan Perwakilan Rakyat Daerah (DPRD), yang nantinya akan ditetapkan sebagai Program Pembentukan Peraturan Daerah (Propemperda).

Bahwa kewenangan sebagaimana dikemukakan di atas, dalam implementasi atau pelaksanaannya tidak selalu dapat terlaksana atau berjalan dengan lancar sesuai dengan yang diharapkan, sehingga menyebabkan target atau sasaran yang diinginkan tidak bisa dicapai. Dalam implementasi atau pelaksanaannya secara empirik dihadapkan beberapa kendala. Adapun kendala-kendala yang dihadapi Pemerintahan Daerah dalam pembentukan Peraturan Daerah tersebut, adalah sebagai berikut:

(1) Kendala substansi hukum (legal substance); 
Belum diatur dengan jelas baik di dalam Peraturan Daerah Kota Mataram dan Peraturan Walikota Mataram maupun Peraturan Menteri Dalam Negeri Nomor 80 Tahun 2015 tentang Pembentukan Produk Hukum Daerah, terkait dengan partisipasi masyarakat yang dilaksanakan oleh Pemerintah Daerah dalam hal ini Bagian Hukum Setda Kota Mataram melalui kegiatan konsultasi publik, sehingga terhadap rancangan Peraturan Daerah Kota Mataram pada tataran pelaksanaannya semua rancangan Peraturan Daerah tersebut tidak diadakan konsultasi publik padahal ketentuan untuk melibatkan masyarakat ada pengaturannya dan bila dihubungkan dengan pengertian asas keterbukaan berarti bahwa dalam Pembentukan Peraturan Perundang-undangan mulai dari perencanaan, penyusunan, pembahasan, pengesahan atau penetapan, dan pengundangan bersifat transparan dan terbuka. Dengan demikian, seluruh lapisan masyarakat mempunyai kesempatan yang seluas-luasnya untuk memberikan masukan dalam Pembentukan Peraturan Perundang-undangan. Dengan demikian pelibatan masyarakat secara seluas-luasnya mutlak dilaksanakan oleh Pemerintah Daerah Kota Mataram.

(2) Kendala struktur hukum (legal structure);

Sumber Daya Aparatur Pemerintah Daerah yang memiliki kemampuan dibidang perancangan produk hukum daerah (legislatif drafter) sangat terbatas. Padahal kemampuan Sumber Daya Aparatur ini sangat penting dalam rangka merumuskan rancangan kebijakankebijakan daerah terlebih lagi rancangan Peraturan Daerah. Dari keterangan yang diperoleh bahwa pada Bagian Hukum Setda Kota Mataram hanya memiliki Sumber Daya Aparatur yang memiliki kemampuan dibidang legislatif drafting sebanyak 2 (dua) orang, padahal pekerjaan membuat rancangan produk hukum daerah sangat banyak baik yang bersifat mengatur maupun bersifat penetapan. 
Dengan demikian antara pekerjaan perancangan dengan jumlah personalia yang memiliki kemampuan perancangan produk hukum daerah adalah tidak sebanding.

(3) Kendala di bidang sarana

Salah satu yang penting dalam perancangan produk hukum daerah adalah tersedianya sarana yang memadai, antara lain sarana informasi dan dokumentasi hukum. Sarana ini sangat dibutuhkan mengingat dalam merancang sebuah produk hukum daerah, maka yang harus dipahami lebih awal adalah dasar kewenangan, materi muatan apa yang akan diatur, dasar hukum sebagai rujukan, karenanya informasi dan dokumentasi hukum sangat dibutuhkan, terutama adalah Peraturan Perundang-undangan yang lebih tinggi dan masih berlaku, akan tetapi fasilitas tersebut baru dimiliki oleh Bagian Hukum Setda Kota Mataram pada tahun 2016. ${ }^{11}$ Ditambah lagi dengan hasil inovasi Bagian Hukum Sekretariat Daerah Kota Mataram bernama Aplikasi hasil inovasi Bagian Hukum Sekretariat Daerah Kota Mataram bernama Aplikasi PARTNeR (Partisipasi Rakyat Terhadap Pembentukan Regulasi) yang ada dan dilaunching pada 5 Maret 2018, sebagai upaya memaksimalkan peran serta masyarakat untuk terlibat dalam pembentukan regulasi, dengan demikian regulasi akan hadir memenuhi kebutuhan masyarakat dan bisa memberikan payung hukum yang berpihak pada masyarakat ${ }^{12}$. Namun operator aplikasi tersebut dan dasar hukum penggunaanya belum ada.

(4) Kendala budaya hukum (legal culture);

Lamanya koordinasi antar lembaga/ instansi terkait dalam melakukan kajian terhadap materi maupun substansi Rancangan Peraturan Daerah yang berasal dari inisiatif Dewan Perwakilan Rakyat Daerah (DPRD) Kota Mataram terlebih lagi seringnya ketidak tepatan

\footnotetext{
11 Wawancara dengan, Janur Yudistyo Prabowo, SH,MH, Kasubag Peraturan Peraturan Perundang-undangan Bagian Hukum Setda Kota Mataram, pada tanggal 9 Agustus 2020.

12 https://kabarntb.com/2018/03/pemkot-mataram-launching-aplikasi-partner/
} 
waktu lembaga/ instansi terkait dalam memberikan jawaban kajian teknis terkait Rancangan Peraturan Daerah dimaksud.

Sehubungan dengan kendala-kendala yang dihadapi Pemerintah Daerah dalam pembentukan Peraturan Daerah Kota Mataram sebagaimana diuraikan sebelumnya, maka berikut ini akan diuraikan mengenai solusi yang dilakukan dalam rangka mengatasi kendalakendala yang dihadapi tersebut.

Meskipun Belum diatur dengan jelas baik di dalam Peraturan Daerah Kota Mataram dan Peraturan Walikota Mataram maupun Peraturan Menteri Dalam Negeri Nomor 80 Tahun 2015 tentang Pembentukan Produk Hukum Daerah, tidak diatur secara jelas terkait dengan hak masyarakat untuk berpartisipasi dalam pembentukan Peraturan Daerah khususnya pembentukan Peraturan Daerah Kota Mataram, dalam tataran pelaksanaannya, pihaknya selalu melakukan koordinasi secara intensif bersama Anggota Tim Pembentukan Produk hukum daerah yang telah dibentuk melalui Keputusan Walikota Mataram dalam rangka menghasilkan Peraturan Daerah yang sesuai dengan amanat Ketentuan Peraturan Perundang-undangan yang berlaku. $^{13}$

Dalam hal menyikapi kurangnya Sumber Daya Aparatur Pemerintah Daerah yang memiliki kemampuan dibidang perancangan produk hukum daerah (legislatif drafter), pihaknya dalam hal ini dibentuk tim pengkajian peraturan perundang-undangan sehingga keterbatasan Sumber Daya Aparatur yang memiliki kemampuan dibidang perancangan produk hukum daerah (legislatif drafter) dapat teratasi.

Dalam hal keterbatasan sarana informasi dan dokumentasi hukum guna menunjang kegiatan pembentukan produk hukum daerah, pihaknya telah berupaya memanfaatkan fasilitas yang ada berupa

13 Wawancara dengan, DR.Hubaidi, SH., MH Kepala Bagian Hukum Setda Kota Mataram, pada tanggal 15 Agustus 2020. 
layanan internet dan di tahun anggaran 2016 Bagian Hukum Setda Kota Mataram telah meluncurkan Website Sistem Jaringan Dokumentasi dan Informasi Hukum (SJDIH) sehingga dapat memudahkan semua pihak dalam mendapatkan aturan-aturan yang baru disahkan maupun mempublikasikan Rancangan Maupun Peraturan Daerah yang sedang dibahas atau yang sudah ditetapkan. Selanjutnya pada Aplikasi hasil inovasi Bagian Hukum Sekretariat Daerah Kota Mataram bernama Aplikasi PARTNeR (Partisipasi Rakyat Terhadap Pembentukan Regulasi), sebagai upaya memaksimalkan peran serta masyarakat untuk terlibat dalam pembentukan regulasi, dengan demikian regulasi akan hadir memenuhi kebutuhan masyarakat dan bisa memberikan payung hukum yang berpihak pada masyarakat akan tetapi operator aplikasi tersebut dan dasar hukum penggunaanya belum ada dan sampai sekarang belum ada upaya untuk mengatasi hal tersebut.

Dalam Proses Pembentukan Peraturan Daerah Kota Mataram pada tataran pelaksanaannya selalu melibatkan lembaga/ Instansi terkait mengingat keberadaan Bagian Hukum Setda Kota Mataram hanya sebagai Supporting System ${ }^{14}$, dimana melakukan sinkronisasi dan harmonisasi terhadap peraturan perundang-undangan yang lebih tinggi, kemudian melakukan koordinasi dengan jajaran Perangkat Daerah (PD) terkait maupun lembaga-lembaga vertikal yang dinilai memiliki kompentensi terhadap keberadaan Rancangan Peraturan daerah Kota Mataram. Melakukan kegiatan koordinasi bukanlah suatu hal yang mudah mengingat diperlukan komitmen yang lebih antara satu dan lainnya, apalagi dalam hal melakukan pengkajian terhadap Rancangan Peraturan Daerah Kota Mataram yang melibatkan banyak lembaga/instansi terkait yang masing-masing memiliki tugas

14 Wawancara dengan, DR.Hubaidi, SH., MH Kepala Bagian Hukum Setda Kota Mataram, pada tanggal 15 Agustus 2020. 
dan fungsi yang tidak kalah padatnya dengan Bagian Hukum Setda Kota Mataram selaku koordinator, sehingga tidak dapat dipungkiri jawaban dari lembaga/instansi terkait yang dikendaki cepat menjadi agak lama. Akan tetapi dalam hal melakukan koordinasi tersebut pihaknya telah menyusun strategi dengan cara mengundang lembaga/instansi terkait untuk melaksanakan rapat koordinasi dengan melampirkan terlebih dahulu naskah rancangan Peraturan Daerah, yang kemudian masing-masing perwakilan dari lembaga/instansi terkait dapat hadir dengan tepat waktu sekaligus membawa hasil kajian teknis dari rancangan Peraturan Daerah dimaksud.

\section{SIMPULAN}

Dalam Proses pembentukan Peraturan Daerah Pemerintahan Kota Mataram pada tataran pelaksanaannya sudah memberikan ruang partisipasi masyarakat di dalam pembentukannya dengan adanya Aplikasi hasil inovasi Bagian Hukum Sekretariat Daerah Kota Mataram yang diberi nama Aplikasi PARTNeR (Partisipasi Rakyat Terhadap Pembentukan Regulasi) yang dilaunching pada 5 Maret 2018, sebagai upaya memaksimalkan peran serta masyarakat untuk terlibat dalam pembentukan regulasi, dengan demikian regulasi akan hadir memenuhi kebutuhan masyarakat dan bisa memberikan payung hukum yang berpihak pada masyarakat, namun operator aplikasi tersebut dan dasar hukum penggunaanya belum ada sehingga menyebabkan tidak terpakainya aplikasi dimaksud, sehingga dengan demikian dapat dikatakan Proses pembentukan Peraturan Daerah Pemerintahan Kota Mataram belum maksimal, selain hal tersebut Peraturan Daerah yang diajukan oleh Pemerintah Daerah cenderung berkarakter ortodoks karena bersifat positivis-instrumentalis, artinya memuat materi yang lebih merefleksikan visi sosial dan politik pemegang kekuasaan atau memuat materi yang lebih merupakan alat untuk mewujudkan kehendak dan 
Jurnal SOSIO DIALEKTIKA 6 (1) (2021)

P-ISSN: 2540.8941 e-ISSN: 2623.2944

sosiodialektika@unwahas.ac.id
Pelaksanaan Partisipasi

Masyarakat Dalam Proses

Pembentukan Peraturan Daerah

(Studi Di Kota Mataram)

kepentingan program pemerintah (top down). Kemudian proses pembuatannya yang bersifat sentralistik, serta dari segi penafsiran maka produk hukumnya memberi peluang luas kepada pemerintah untuk membuat berbagai interpretasi dengan berbagai peraturan lanjutan.

Dalam tataran pelaksanaan insiatif mengajukan rancangan Peraturan Daerah Kota Mataram tidak dapat dipungkiri menemui berbagai Kendala baik terhadap Pemerintah Daerah Kota Mataram, antara lain :

(1) Di bidang substansi hukum (legal substance), dimana masih belum terdapat aturan yang jelas terkait dengan partisipasi masyarakat dalam pembentukan Peraturan Daerah, baik dalam Peraturan Daerah Kota Mataram dan Peraturan Walikota Mataram.

(2) Di bidang struktur hukum (legal structure), dimana terbatasnya kemampuan Sumber Daya aparatur pemerintah daerah;

(3) Di bidang sarana, dimana kurangnya sarana Informasi dan Dokumentasi Hukum yang terdapat di Bagian Hukum Setda Kota Mataram, ditambah dengan belum adanya operator yang mengoperasikan Aplikasi PARTNeR (Partisipasi Rakyat Terhadap Pembentukan Regulasi) serta belum adanya dasar hukum pemanfaatannya;

(4) Di bidang budaya hukum (legal culture), dimana dalam melakukan koordinasi dengan lembaga/ instansi terkait, sering kali ketidak tepatan waktu dalam memberikan jawaban kajian teknis terkait Rancangan Peraturan Daerah dimaksud. 


\section{DAFTAR PUSTAKA}

Bagir Manan (2006), dalam Ridwan HR, Hukum Admnistrasi Negara, PT.Raja Grafindo Persada, Jakarta,.

Darmini. (2018 )"Pembentukan Peraturan Daerah Yang Responsif Melalui Inisiatif DPRD Kota Mataram”. Jurnal IUS Kajian Hukum dan Keadilan Volume VI Nomor 2 Tahun.

Gafar, Afan. (2004), Politik Indonesia Transsisi menuju Demokrasi, Pustaka Pelajar,Yogyakarta,.

Maria Farida Indrati S.,( 2007) Ilmu Perundang-Undangan, jenis, fungsi dan materi muatan, Kanisius, Jogjakarta,.

Mahfud MD, Moh. (2011) Politik Hukum Di Indonesia, Jakarta, Rajawali Pers,.

Santosa, Mas Achmad. Good Governance dan Hukum Lingkungan, (Jakarta: ICEL, 2001).

Praptanugraha, (2008), Partisipasi Masyarakat Dalam Pembentukan Peraturan daerah, Jurnal Hukum No. 3 vol. 15 juli : 459 - 473

W. Riawan Tjandra dan Kresno Budi Sudarsono,( 2009), Legislative Drafting: Teori dan Teknik Pembuatan Peraturan Daerah, Penerbit Universitas Atmajaya, Yogyakarta,

https://kabarntb.com/2018/03/pemkot-mataram-launching-aplikasi-partner/

Undang-Undang Nomor 23 Tahun 2014 tentang Pemerintahan Daerah (Lembaran Negara Republik Indonesia Tahun 2014 Nomor 244, Tambahan Lembaran Negara Republik Indonesia Nomor 5587) sebagaimana telah diubah beberapa kali terakhir dengan Undang-Undang Nomor 9 Tahun 2015 tentang Perubahan Kedua Atas Undang-Undang Nomor 23 Tahun 2014 tentang Pemerintahan Daerah (Lembaran Negara Republik Indonesia Tahun 2015 Nomor 58, Tambahan Lembaran Negara Republik Indonesia Nomor 5679).

Undang-Undang Nomor 12 Tahun 2011 tentang Pembentukan Peraturan Perundang-Undangan (Lembaran Negara Republik Indonesia Tahun 2011 Nomor 82, Tambahan Lembaran Negara Republik Indonesia Nomor 5234). 
Peraturan Pemerintah Nomor 45 Tahun 2017 tetang Partisipasi Masyarakat Dalam Penyelenggaraan Pemerintahan Daerah. (Lembaran Negara Republik $\begin{array}{lllll}\text { Indonesia } & \text { Tahun } & 2017 & 7 & \text { Nomor }\end{array}$ Tambahan Lembaran Negara Republik Indonesia Nomor 6133)

Peraturan Presiden Nomor 87 Tahun 2014 tentang Petunjuk Pelaksanaan UndangUndang Nomor 12 Tahun 2011 tentang Pembentukan Peraturan PerundangUndangan.

Peraturan Menteri Dalam Negeri Nomor 80 Tahun 2015 tentang Pembentukan Produk Hukum Daerah (Berita Negara Republik Indonesia Tahun 2015 Nomor 2036). Sebagaimana telah diubah dengan Peraturan Menteri Dalam Negeri Nomor 120 Tahun 2018 tentang Perubahan Atas Peraturan Menteri Dalam Negeri Nomor 80 Tahun 2015 tentang Pembentukan Produk Hukum Daerah. (Berita Negara Republik Indonesia Tahun 2018 Nomor 157). 